УДК 349.2(477):305

DOI https://doi.org/10.32837/apdp.v0i83.135

О.Г.Середа, А.О. Кушніренко

\title{
АКТУАЛЬНІ ПИТАННЯ ҐЕНДЕРНОЇ РІВНОСТІ У ТРУДОВОМУ ПРАВІ УКРАЇНИ В УМОВАХ ЕВРОІНТЕГРАЦІЇ
}

Постановка проблеми. В умовах процесу поступової інтеграції України до Європейського Союзу відбувається адаптація різних сфер суспільного життя до європейських стандартів. Міжнародне надбання в царині праці зобов’язує Україну втілювати в трудові відносини певні засади і принципи (верховенства права, гуманності, демократизації виробничих відносин, гарантованості трудових прав та іншого), які набувають усе ширшого застосування та є запорукою трансформації і модернізації як у процесі виробничої діяльності, так і взагалі в розбудові правової держави та поступового наближення України до Європейського Союзу.

Одним із найактуальніших питань, що постають в обговореннях у ЄС та світовій спільноті, на сьогоднішній день $є$ гендерна рівність, зокрема у трудовому праві. Йдеться про підвищення рівня представництва жінок на керівних посадах, рівний розподіл робочих місць між жінками та чоловіками, запровадження спеціальних курсів для підготовки працівників до професій, які стереотипно вважалися «жіночими або чоловічими" тощо.

Аналіз останніх досліджень і публікацій. Дослідженням питання гендерної рівності в трудовому праві займалися не лише науковці в царині трудового права чи юриспруденції взагалі, а й дослідники у сфері економіки, соціології, політології, психології. Слід згадати досягнення таких вчених, як В. Венедіктова, М. Світенок, О. Коваленко, Р. Шабанов, Н. Мельничук, І. Новак, Т. Бурейчак, Т. Марценюк та інших. Але попри таке детальне дослідження цього питання, можна стверджувати, що в умовах постійного розвитку нашого суспільства проблема й досі стоїть дуже гостро, і виникають нові питання стосовно ґендерної рівності у трудовому праві, які ще не зайшли своє повне відображення у наукових працях.

Метою статті є дослідження та аналіз світової практики врегулювання ґендерного питання в царині трудових відносин та визначення шляхів вдосконалення національного трудового законодавства з урахуванням сучасних міжнародних стандартів у сфері праці.

Виклад основного матеріалу дослідження. У ході аналізу наукових та дослідницьких матеріалів, що стосуються однієї з найбільш гострих проблем у сфері праці, а саме гендерної дискримінації, встановлено, що дискримінація за ознакою статті склалася історично. Зокрема, це зумовлено привілейованим становищем чоловіків ще в стародавні часи, коли жінкам заборонялося приймати участь в державних справах, на них покладався обов'язок у всьому прислухатися та підпорядковуватися чоловікові. Не вдаючись до аналізу історії та причин виникнення цієї ситуації, оскільки з цього приводу вже здійснено ряд досліджень, автори зазначають, що останнім часом ця проблема все більше привертає увагу міжнародної спільноти та правозахисних організацій. Зокрема, у сучасному міжнародному пра-

() О. Г. Середа, А. О. Кушніренко, 2019 
ві державами-членами ООН розроблено, укладено й ратифіковано понад 20 міжнародних конвенцій, спеціально присвячених тим чи іншим питанням захисту прав жінок. Питання рівних прав і можливостей жінок і чоловіків є одним із провідних у діяльності Європейського Союзу. Серед проблем, що мають бути вирішеними, Рада Європи називає також узгодження сімейного і професійного життя жінки i чоловіка; надання можливості людям здійснювати їх рівні права [1, с. 467-468].

Найбільш яскравий відбиток у свідомості людей залишила модель поведінки радянської жінки, що породило багато стереотипів щодо ефективності працівників жіночої статі. Слід наголосити, що треба змінювати таке ставлення людей до вибору своєї трудової діяльності. Адже не має суто «чоловічних» чи суто «жіночих» професій, тому кожен індивід має право обрати саме ту роботу, яка буде приносити йому задоволення. Це спонукатиме працівників старанно виконувати свої функції, що в свою чергу, підвищуватиме ефективність виробництва на підприємстві, в установі, організації.

Крім того, сьогодні актуальним питанням є підвищення ролі репродуктивної праці жінок, а саме надання цьому явищу особливого значення. Вітчизняне трудове законодавство традиційно приділяє увагу захисту права на материнство, забезпеченню можливості поєднання праці та виховання дітей. Все одно існують причини, що є перешкодою в реалізації репродуктивних планів жінок: неприпустимі матеріальні умови; невпевненість щодо завтрашнього дня; несприятливі житлові умови; відсутня підтримка влади; незадовільний стан здоров'я, екологічної ситуації; труднощі виховання дітей та догляду за ними; втрата професіоналізму і зниження конкурентоздатності на ринку праці. Тому вважається за необхідне цілеспрямовано виділити комплекс заходів гендерного характеру, в тому числі направленого на те щоб надати особливого статусу репродуктивній праці жінок.

Важливо звернути увагу на нестандартні форми зайнятості, покращення умов праці і соціального захисту жінок. Отже, необхідно усвідомити несправедливість такого соціального порядку, який занижує можливість конкурентоспроможності жінки на ринку праці і в контексті ринкових відносин виглядає немотивованим [2, с. 258-259]. Тоді б жінка змогла і ефективно виконувати свою трудову функцію, і народжувати дітей із впевненістю в тому, що вона надалі зможе забезпечувати себе і свою родину. На думку авторів, це сприяло б належному функціонуванню прописаного у національному законодавстві принципу ґендерної рівності у трудовому праві, а також покращило б стан народжуваності в Україні.

Слід враховувати поширеність гендерної дискримінації у сфері праці, спеціальні норми, направлені на її подолання, прийняті стосовно жінок. Такі норми щодо правового регулювання праці жінок можна поділити на дві групи: 1) норми, що становлять сутність диференціації, яка пов'язана з фізіологічними особливостями жіночого організму, їх репродуктивною функцією; 2) норми в рамках політики позитивних дій, направлені на створення додаткових умов для подолання гендерної рівності. Водночас на практиці наявність значної кількості додаткових пільг та гарантій для жінок не завжди забезпечує для них рівність можливостей, а навпаки іноді стає причиною дискримінації. Тому в XXI ст. у багатьох країнах Заходу та частково в міжнародному праві спостерігається тенденція переходу від захисного 
до антидискримінаційного законодавства щодо жінок, тобто поступове скасування правових норм, які встановлюють спеціальну охорону праці жінок, за винятком охорони праці вагітних жінок та жінок-матерів. Так, Конвенція ООН про ліквідацію всіх форм дискримінації щодо жінок, Свропейська соціальна хартія (переглянута), Директива ЄС 76/207 тощо відображають принцип, згідно з яким обмеження роботи жінок у нічний час виправдані тільки у випадку материнства [6, с. 204-205].

Дослідники питання ґендерної рівності часто спираються на досвід країн Європи, Північної Америки та Скандинавських країн. Так, у Канаді в систему професійно-технічного навчання введені спеціальні курси для підготовки жінок і чоловіків до професій, які стереотипно вважалися «жіночими або чоловічими». Наприклад, професії первинного та поточного обслуговування хворих, соціального догляду за інвалідами, дітьми; робітничі спеціальності з теслярства, слюсарства, зварювання тощо є гостродефіцитними та забезпечують працівників стабільним доходом в Канаді. Ці потреби ринку праці враховано в програмах навчання та перенавчання дорослих. Для такого навчання розроблені спеціальні гендерно чутливі методики та матеріали, які забезпечують комфортне навчальне середовище та сприяють розширенню можливостей для професійної реалізації жінок і чоловіків у відповідності до потреб ринку праці. Наприклад, жінок заохочують до професій з обслуговування автомобілів, верстатів, технологічного будівництва; а чоловіків готують до професій із надання допоміжних медичних послуг та послуг із соціального захисту (догляд за хворими, інвалідами, дітьми тощо).

Гендерно відповідальні підходи сприяють вирівнюванню ресурсного забезпечення ринку праці та зменшенню розриву в оплаті праці жінок і чоловіків. Досвід таких установ, як Саскачеванський інститут прикладних наук і технологій (провінція Саскачеван, Канада), застосовують не лише в Канаді, але й в світових практиках, у тому числі й в Україні [3, с. 35]. Щодо жінок у Швеції здійснюється політика покращення можливостей на ринку праці, щоб жінки мали однакові 3 чоловіками умови для оплачуваної праці, однакову з чоловіками оплату праці та рівномірний розподіл батьківських обов'язків зі своїми партнерами. Таким чином, одна з головних цілей впровадження ґендерної рівності у Швеції полягає у зменшенні ґендерної сегрегації на ринку праці та водночас стимулювання відповідальності чоловіків за участь у веденні домогосподарства та догляд за дітьми [4, с. 191].

У Норвегії в 2003 році були запроваджені квоти на представництво жінок у керівництві підприємств, установ та організацій. Ці квоти передбачають, що приблизно 40\% жінок Норвегії мають займати керівні посади. На сьогоднішній день кількість жінок, що управляють норвезькими підприємствами, установами та організаціями, перевищує $40 \%$. Наступною країною, що пішла таким же шляхом, була Іспанія, яка в 2007 році передбачила в своєму законодавстві схожі положення щодо представництва жінок на керівних посадах. Варто сказати, однією з останніх країн, що таким чином впроваджують політику гендерної рівності в трудове право, є Франція. Парламент Франції вирішив, що французькі підприємства, які не мають у своєму керівництві жодної жінки, мусять якнайшвидше призначити на керівні посади осіб жіночої статі [5]. 
Низка країн запровадили заходи стимулювання ґендерного балансу в керівних органах компаній. Ісландія (45\%), Франція (44\%) та Норвегія $(40 \%)$ є лідерами за показниками диверсифікованого представництва у Європі. Найбільш релевантним прикладом для України є Австрія, що спершу запровадила квоти виключно для наглядових рад державних компаній, з 2018 року квоти стосуються приватних компаній також. Представництво жінок збільшилося з $26 \%$ у 2011 році до $47 \%$ у 2017. Запровадження «м'яких» заходів, що не передбачають штрафних санкцій за невиконання, виявилося неефективним, за виключенням Швеції (36\%) та Великобританії (30\%) [6].

Гендерні диспропорції та дискримінація на національному ринку праці викликані рядом причин, зокрема професійною сегрегацією, наявністю ряду додаткових пільг для жінок у сфері праці, які зменшують їх конкурентоспроможність, існуванням у роботодавців упереджень щодо осіб цієї статі, їх можливостей тощо. Незважаючи на існування диспропорцій щодо зайнятості та оплати праці за статевою ознакою, в Україні практично відсутні фахові соціологічні дослідження з питань ґендерної рівності на державному рівні. Питаннями ґендерної оцінки ринку праці цікавляться, переважно, міжнародні інституції та національні правозахисні організації [7, с. 203].

Національне трудове право теж потребує запровадження програм інтеграції жінок у «чоловічі» професії, а чоловіків - у «жіночі». Звичайно, в чинному Кодексі законів про працю України визначено, що забороняється будь-яка дискримінація у сфері праці, зокрема порушення принципу рівності прав і можливостей, пряме або непряме обмеження прав працівників залежно від статі, ґендерної ідентичності, сексуальної орієнтації. Найвичерпніші стандарти містяться в Конвенції МОП про дискримінацію у сфері праці і зайнятості № 111 [8] і Рекомендація МОП № 111 [9], що були прийняті у 1958 році. Відповідно до мети цієї Конвенції термін «дискримінація» охоплює: будь-яке розрізнення, недопущення або перевагу, що робиться за ознакою раси, кольору шкіри, статі, релігії, політичних переконань, іноземного походження або соціального походження і призводить до знищення або порушення рівності можливостей чи поводження в галузі праці та занять. Україна як держава-учасниця цієї Конвенції зобов’язалась внести принцип однакових прав чоловіків та жінок до своєї Конституції та іншого відповідного законодавства і забезпечити за допомогою закону або інших відповідних засобів практичне здійснення цього принципу; вживати законодавчих та інших заходів, зокрема санкції, які забороняють будь-яку дискримінацію щодо жінок; встановити юридичний захист прав жінок на однаковій основі з чоловіками та забезпечити за допомогою компетентних національних судів та інших державних установ ефективний захист жінок проти будь-якого акту дискримінації; утримуватися від вчинення будь-яких дискримінаційних актів або дій стосовно жінок і гарантувати, що державні органи та установи діятимуть відповідно до цього зобов’язання; вживати всіх відповідних заходів для ліквідації дискримінації щодо жінок з боку будь-якої особи, організації або підприємства; вживати відповідних заходів, зокрема законодавчих, стосовно зміни або скасування чинних законів, постанов, звичаїв і практики, які є дискримінацією щодо жінок; скасувати всі положення свого кримінального законодавства, які є 
дискримінацією щодо жінок [10, с. 23]. Важливо зазначити, що відсутній механізм забезпечення такої рівності прав та можливостей.

За даними сайту Державної служби статистики України, з січня 2019 року по березень 2019 року серед зайнятого населення України працездатного віку виділяють $45 \%$ жінок (7902,9 тис. осіб) та 57,6\% чоловіків (8452,6 тис. осіб) до всього населення відповідного віку [11].

Попри те, що 53,7\% населення України становлять жінки, вони непропорційно представлені в органах влади й бізнесу і, в основному, отримують заробітну плату на $24 \%$ менше чоловіків. Найменше жінки представлені в транспортному, будівельному, промисловому та енергетичному секторах [6]. Отже, різниця у зайнятості чоловіків і жінок є достатньо помітною, і така ситуація вимагає вирішення.

На актуальності цього питання у вітчизняному правовому просторі наголошує і законотворець. Так, у Верховній Раді зареєстровано законопроект № 9528 від 4 лютого 2019 року «Про внесення змін до законодавчих актів України для забезпечення рівних прав та можливостей громадян у представництві в наглядових радах та органах правління державних унітарних підприємств, господарських товариств і державних банків», яким передбачається запровадження норми про обов'язковість представництва професіоналів кожної статі на рівні 40 відсотків у наглядових радах державних унітарних підприємств, господарських товариств, у статутному капіталі яких понад 50 відсотків акцій (часток) належать державі, та державних банків [12].

Проблема забезпечення рівного становища працюючих жінок і чоловіків у сучасних умовах знаходить нове осмислення з огляду на процес подальшої трансформації суспільно-економічного устрою в Україні. Індивідуалізація інтересів, зміщення акцентів на захист прав окремої особистості активізують висвітлення рівня юридичного та фактичного закріплення можливостей жінки і чоловіка як людини у сфері праці. Економічна самостійність суб'єктів господарювання об'єктивно зумовлює прагнення роботодавця забезпечити ефективність виробничої діяльності, стимулює пошук шляхів її здешевлення та отримання більшого прибутку, що значним чином позначається на упередженому ставленні при виборі працівників. Відповідно до ст. 24 Конституції України жінки мають рівні з чоловіками права і свободи. Конкретизація цього конституційного принципу щодо трудових правовідносин полягає у тому, що жінки нарівні з чоловіками мають право на реалізацію усіх наданих законодавством про працю можливостей щодо застосування своєї здатності до продуктивної праці у різних галузях суспільного виробництва. Рівність жінок у сфері трудових відносин забезпечується наданням їм однакових із чоловіками можливостей у професійній підготовці, праці та винагороді за неї [13, с. 124].

На практиці найбільші проблеми щодо недотримання рівності прав чоловіків і жінок у трудових відносинах постають при працевлаштуванні жінок. Дійсно, роботодавці при прийнятті на роботу жінок звертають увагу на те, чи заміжня жінка, чи $є$ в неї родина та діти тощо. Вони переймаються тим, що жінка-працівник не зможе ефективно виконувати свою трудову функцію, бо її буде відволікати сімейне побутове життя, догляд за дітьми та ведення домашнього господарства. Крім того, 
невигідно приймати на роботу жінку, яка потім в будь-який час може завагітніти, і за нею буде зберігатися її робоче місце, а роботодавець буде вимушений знов шукати нового працівника. Всі ці аспекти заважають ефективній реалізації принципу рівності у трудовому праві на практиці, що призводить збільшення кількості працюючих чоловіків і зменшення кількості працюючих жінок.

Гендерна рівність щодо зайнятості за професійними групами існує лише серед працівників найпростіших професій. Стійка перевага зайнятих чоловіків притаманна професійним групам, що належать до робітничих професій, законодавцям, вищим державним службовцям і керівникам. Поглиблення диспаритету наявне у більшості професійних груп, крім професіоналів і працівників, зайнятих у сфері обслуговування та торгівлі [14, с. 34]. Деякі дослідники вважають, що забезпечення ґендерної рівності має стати невід’ємною частиною соціальної політики нашої держави. Крім того, необхідно дещо змінити рівень гендерної професійної сегрегації. Це стане можливим, якщо Україна буде обмінюватися досвідом і знаннями з іншими країнами Європи, щоб потім розробити стратегії, які будуть спрямовані на запобігання виробничим ризикам і небезпекам для того, щоб деякі галузі виробництва стали більш доступні для жінок [15, с. 371].

Висновки. Враховуючи необхідність реформування вітчизняного трудового законодавства з урахуванням міжнародних стандартів та вимог сьогодення, автори наголошують на актуальності розробки в Україні державної програми щодо встановлення гендерної рівності. Адаптація зарубіжного досвіду в цій сфері повинна втілюватися на рівні новел нового Трудового кодексу, які б передбачали не лише принцип недопущення дискримінації, зокрема за статевою ознакою, але й передбачали процедуру дотримання цього принципу та дієві механізми захисту.

\section{Jimepamypa}

1. Мельничук Н.О. Гендерна рівність в аспекті реалізації принципу договірного регулювання праці. Форум права. 2011. № 4. С. 466-471.

2. Збаржевецька Л.Д., Самсонова К.В. Гендерна рівність у сфері праці. Наукові праці Кіровоградського національного технічного університету. 2010. № 18. С. 255-262.

3. Топ-10 Гендерної політики / за ред. М.М. Ілляш. Київ : Ла Страда Україна, 2015. 48 с.

4. Бурейчак Т., Марценюк Т. Скандинавська утопія? Гендерна рівність і трудові vs. репродуктивні ресурси у Швеції. Спільне. 2013. № 6. С. 189-194.

5. Міжнародний досвід запровадження гендерних квот та українські реалії. Гендер в деталях : вебсайт. URL: https://genderindetail.org.ua/season-topic/polityka/mizhnarodniy-dosvid-zaprovadzhennyagendernih-kvot-ta-ukrainski-realii-134924.html (дата звернення: 13.10.2019).

6. Верховна Рада зареєструвала законопроект щодо гендерних квот у наглядових радах державних підприємств. Інтерфакс-Україна Інформаційне агентство : веб-сайт. URL: https://ua.interfax.com.ua/ news/press-release/566807.html (дата звернення: 5.10.2019).

7. Сахарук І.С. Забезпечення гендерної рівності як напрям реалізації концепції гідної праці в Україні. Актуальні проблеми трудового законодавства, законодавства про державну службу та службу в правоохоронних органах:матеріали VII Всеукраїнської наук.-практ. конф. (Харків, 16 листопада 2018 р.). Харків : ХНУВС, 2018. С. 203-206.

8. Про дискримінацію в галузі праці та занять : Конвенція МОП від 25.06.1958 р. № 111. URL: https://zakon.rada.gov.ua/laws/show/993_161 (дата звернення: 13.10.2019).

9. Щодо дискримінації в галузі праці та занять: Рекомендація МОП від 25.06.1958 р. № 111. URL: https://zakon.rada.gov.ua/laws/show/993_602 (дата звернення: 13.10.2019).

10. Дорош О. Гендерна рівність у контексті концепції гідної праці: стан, основні проблеми та шляхи їх вирішення. Україна: Аспекти пращі. 2011. № 7. С. 21-25. 
11. Зайнятість населення за статтю, типом місцевості та віковими групами. Державна служба статистики України : веб-сайт. URL: http://www.ukrstat.gov.ua/operativ/operativ2017/rp/eans/eans_u/ arch_znsmv_u.htm (дата звернення: 22.09.2019).

12. Про внесення змін до законодавчих актів України для забезпечення рівних прав та можливостей громадян у представництві в наглядових радах та органах правління державних унітарних підприємств, господарських товариств і державних банків: Проект Закону України від 04.02.2019 № 9528. URL: http://w1.c1.rada.gov.ua/pls/zweb2/webproc4_1?pf3511=65413 (дата звернення: 22.09.2019).

13. Венедіктова В.М. Гендерна рівність в процесі реалізації трудової функції. Право $і$ безпека. 2005. № 4. С. 123-127.

14. Новак I.М. Гендерна рівність і базові індикатори ринку праці в Україні. Науковий вісник Полтавського університету споживчої кооперацї̈ України. 2010. № 4. С. 30-34.

15. Світенок M.I. Проблеми ґендерної рівності у законодавстві про працю України. Держава і право. 2010. № 48. С. $365-372$.

\section{Анотація}

Середа О. Г., Кушніренко А. О. Актуальні питання гендерної рівності у трудовому праві України в умовах євроінтеграції. - Стаття.

У науковій статті розглянуто сучасні проблеми реалізації нормативно закріплених положень стосовно гендерної рівності у трудовому праві України. Дослідження цього питання зумовлено розвитком процесу інтеграції України до Європейського Союзу, що передбачає активну адаптацію українського національного законодавства до встановлених європейських стандартів. Наголошується, що незважаючи на існування диспропорцій щодо зайнятості та оплати праці за статевою ознакою, в Україні практично відсутні фахові дослідження з питань гендерної рівності на державному рівні.

Досліджено проблеми поглиблення диспаритету чоловіків та жінок при працевлаштування та на інших етапах розвитку трудових відносин. Проаналізовано критерії диференціації правового регулювання праці з урахуванням особливостей підвищення ролі репродуктивної праці жінок та наголошено на необхідності виділення комплексу заходів гендерного характеру, направленого на те, щоб надати особливого статусу репродуктивній праці.

Вдосконалено теоретичні підходи до питань ґендерної диспропорції та ґендерних квот в умовах флексібілізації трудових відносин та розвитку нестандартних форм зайнятості. 3 урахуванням аналізу наукової літератури, практичних аспектів та офіційних статистичних даних, висвітлені основні актуальні аспекти розгляду поставленої проблематики існування гендерної нерівності у трудових відносинах.

Досліджено міжнародний досвід щодо боротьби із ґендерною нерівністю та запропоновані шляхи подолання вказаної проблеми у вітчизняному трудовому законодавстві в умовах його реформування 3 метою підвищення конкурентоспроможності жіночої праці. Знайшли подальшого розвитку пропозиції нормативного врегулювання питання та запровадження надійних механізмів реалізації правових норм щодо гендерної рівності в Україні.

На підставі проведеного дослідження запропоновано зміни до чинних нормативних актів щодо рівності представництва інтересів жінок і чоловіків у трудових відносинах, зокрема, пропорційна участь в управлінні об'єктами господарювання. Наголошується на впровадженні дієвих правових та економічних механізмів для забезпечення функціонування ґендерної рівності в умовах євроінтеграційних процесів в Україні.

Ключові слова: квоти на представництво, диспропорції зайнятості, диспаритет при працевлаштуванні, репродуктивна праця, дискримінація.

\section{Summury}

Sereda O. H., Kushnirenko A. O. Actual issues of gender equality in labor law of Ukraine in circumstances of the Eurointegration. - Article.

The scientific article deals with contemporary problems of the implementation of the legal statements about gender equality in the labor law of Ukraine. Research of this issue is caused by development of the integration process of Ukraine to the European Union, which supposes active adaptation of the Ukrainian national legislation to the established European standards. It is emphasized that despite of the existence of gender disproportion in employment and remuneration, there are not practically any professional studies of gender equality at the state level in Ukraine.

The problems of aggravation of men's and women's disparity in employment and at the other stages of the development of labor relations are investigated. The measures of differentiation of legal regulation of labor are analyzed in view of features of increasing the role women's reproductive labor and the necessity 
of need to identify a complex of measures of gender nature aimed at giving special status to reproductive labor is emphasized. Theoretical approaches to gender disproportion and gender quotas in conditions of flexibilisation of labor relations and development of nonstandard forms of employment are improved.

Considering the analysis of scientific literature, practical aspects and official statistics, the main relevant aspects of review of the existence of gender inequality in labor relations are got across. The international experience at struggle with gender inequality is researched and the ways of solution of this problem in the domestic labor legislation in circumstances of its reform with a view to increase the competitive ability of women's labor are proposed. The propositions of the normative settlement of the issue and introduction of safe mechanisms for implementation of legal norms about gender equality in Ukraine found further development.

On the grounds of conducted research, changes to the current normative acts about equality of representation of women's and men's interests in labor relations are proposed, in particular, proportional participation in the management of business objects. The introduction of effective legal and economic mechanisms for provision of the functioning of gender equality in the context of European integration processes in Ukraine are emphasized.

Key words: quotas of representation, disproportions in occupation, disparity in employment, reproductive labor, discrimination. 